A N N A L ES

UNIVERSITATIS MARIAE CURIE-SKŁODOWSKA

LUBLIN - POLONIA

VOL. LXVI, 1

SECTIO G

2019

Uniwersytet Marii Curie-Skłodowskiej w Lublinie

ARKADIUSZ BEREZA

arkadiusz.bereza@poczta.umcs.lublin.pl

ORCID: 0000-0002-3964-9179

\title{
Wznowienie i organizacja sądownictwa polskiego w Zamościu w latach 1918-1919
}

Reactivation and Organisation of the Polish Judicial System in Zamość in 1918-1919

W czasie działań militarnych I wojny światowej, w obliczu zagrożenia Zamościa przez wojska państw centralnych, przewodniczący zamojskiego zjazdu sędziów pokoju, miejscowy sędzia pokoju oraz urzędujący w powiecie zamojskim sędziowie gminni zostali w maju 1915 r. ewakuowani w głąb Cesarstwa Rosyjskiego. Oznaczało to koniec rosyjskiej organizacji sądowej na terenach Królestwa Polskiego.

$\mathrm{W}$ celu utrzymania porządku w opuszczonym przez władze rosyjskie mieście przystąpiono do organizacji straży i sądów obywatelskich. Obsada sądów, podobnie jak w całej byłej guberni lubelskiej, została oparta na powołanych przez Centralny Komitet Obywatelski w Warszawie adwokatach i urzędnikach sądowych pochodzenia polskiego, którzy swoje obowiązki sędziowskie wykonywali honorowo'.

W powiecie zamojskim utrzymano cztery sądy gminne, a w mieście Zamościu utworzono jeden sąd pokoju (w miejsce dotychczasowego orzekającego jednoosobowo rosyjskiego sędziego pokoju). Sądy te orzekały w składzie: sędzia pokoju lub sędzia gminny (jako przewodniczący) i dwóch ławników. Urząd zamojskiego sędziego pokoju został we wrześniu 1915 r. objęty przez dr. Romualda Jaśkiewicza, doświadczonego adwokata przysięgłego².

1 W.S. [Wacław Salkowski], Historja Polskich Sądów Obywatelskich w Lublinie, „Biuletyn Towarzystwa Prawniczego w Lublinie" 1916, nr 1, s. 12.

2 Archiwum Państwowe w Lublinie (dalej: APL), Sąd Apelacyjny w Lublinie 1917-1951 (dalej: SAL), Spis zdawczo-odbiorczy (dalej: SZO), nr 1, sygn. 77, k. 54, 80; Pamiatnaja Kniżka Warszawskago Sudiebnago Okruga na 1915 god, Warszawa 1915, s. 76. 
Działalność sądów obywatelskich orzekających w „imieniu prawa” trwała bardzo krótko, gdyż zostały one rozwiązane przez austro-węgierskie władze okupacyjne zaniepokojone zbyt dużą aktywnością społeczności lokalnej. Dokonano reorganizacji sądownictwa, podporządkowując je na terenie okupowanej guberni lubelskiej organom austro-węgierskiego wojskowego generał-gubernatorstwa w Lublinie. Sądami I instancji były sądy pokoju, które od 1 czerwca 1916 r. zastąpiły także dotychczasowe sądy gminne. Instancję apelacyjną stanowiły obwodowe sądy wojskowe orzekające w kompletach złożonych z sędziego koronnego (jako przewodniczącego) i dwóch sędziów pokoju. Sędziów pokoju i sędziów obwodowego sądu wojskowego mianował Komendant Obwodu. Sądy te wydawały wyroki „w imieniu słuszności ustaw i sumienia”3.

W Zamościu funkcjonował sąd pokoju oraz obwodowy (powiatowy) sąd wojskowy. Na czele sądu pokoju pozostał R. Jaśkiewicz. W październiku 1915 r. przyjął on nominację władz okupacyjnych, zastrzegając jednak demonstracyjnie, że nie będzie pobierał $\mathrm{z}$ tego tytułu żadnego wynagrodzenia ${ }^{4}$. Sądem wojskowym w Komendzie Obwodowej (od kwietnia 1917 r. - Powiatowej) kierował mjr Leopold Dorazil. W jego strukturze funkcjonował oddział cywilny, który od 1 sierpnia 1916 r. został zastąpiony przez samodzielny Sąd Powiatowy będący sądem II instancji od orzeczeń sześciu sądów pokoju działających na terenie powiatu zamojskiego. Na jego czele stał Jan Nikisz, sędzia powiatowy delegowany z Galicji. Do właściwości tych sądów nie należały sprawy większej wagi, które rozpatrywały nowo utworzone w Lublinie austriackie sądy okupacyjne, tj. trybunał (pełniący także funkcję sądu powiatowego dla powiatu lubelskiego) i sąd apelacyjny. Były one w większości obsadzone przez sędziów Polaków z Galicji ${ }^{5}$.

Sytuacja militarna państw centralnych w 1916 r. zmusiła je do rewizji stanowiska w sprawie polskiej i poważniejszych ustępstw politycznych wobec Polaków. Aktem z 5 listopada 1916 r. na okupowanych terenach proklamowano Królestwo Polskie, a jego uroczyste ogłoszenie w Zamościu nastąpiło w trakcie wiecu przed Ratuszem ${ }^{6}$. W styczniu 1917 r. rozpoczęła działalność powołana

3 Dziennik Rozporządzeń Zarządu Wojskowego z 14 maja 1916 r. - rozporządzenie z dnia 9 maja 1916 r.; J. Lewandowski, Sądownictwo w Królestwie Polskim w czasie I wojny światowej. Okupacja austro-węgierska, „Annales UMCS. Sectio F” 1974, t. 29, s. 230.

4 APL, SAL, SZO, nr 1, sygn. 77, k. 54.

5 Schematismus des k.u.k. Militär-General-Gouvernements für das österreichisch-ungarische Okkupationsgebiet in Polen, Lublin [b.r.w.], s. 10, 65, 117; W.M., Pięciolecie sądownictwa Polskiego (1917-1922), „Głos Lubelski” 1922, nr 239 (1 września); Sądownictwo cywilne w okupacji austryjacko-wegierskiej 1915-1917, Lublin 1918, s. 9-11, 24, 31; J. Lewandowski, op. cit., s. 230-231; R. Maleszyk, Funkcjonowanie austriackich sądów wojskowych na Lubelszczyźnie w latach 1915-1918, „Annales UMCS. Sectio F” 2013, t. 68, nr 1-2, s. 57-58, 61; idem, Organizacja austriackich wtadz wojskowych na Zamojszczyźnie w latach 1915-1918, „Archiwariusz Zamojski” 2014, s. 45, 49.

6 „Verordnungsblatt für das Generalgouvernement Warschau“ 1916, Nr. 55; K. Radziejewski, Pożegnanie pułkownika Fiszera z Zamościem, „Archiwariusz Zamojski” 2007, s. 89. 
przez niemieckie i austro-węgierskie władze okupacyjne Tymczasowa Rada Stanu Królestwa Polskiego w Warszawie, której zadaniem było zbudowanie zrębów państwowości polskiej w zakresie wyznaczonym przez państwa centralne. W jej strukturach funkcjonował Departament Sprawiedliwości, który miał przygotować projekty aktów prawnych umożliwiających przejęcie w polskie ręce zarządu wymiaru sprawiedliwości i sądownictwa na tych terenach ${ }^{7}$. W efekcie kilkumiesięcznych prac legislacyjnych Tymczasowa Rada Stanu na posiedzeniach w lipcu 1917 r. uchwaliła akty stanowiące podstawę organizacji i działalności sądownictwa królewsko-polskiego. Zostały one wprowadzone w życie rozporządzeniami generał-gubernatorów wojskowych. Zawierały unormowania dotyczące organizacji i struktury sądów królewsko-polskich, przepisy przechodnie do kodeksu postępowania karnego i cywilnego oraz kodeksu karnego, a także o kosztach sądowych i wynagrodzeniach urzędników sądowych ${ }^{8}$.

Z dniem 1 września 1917 r. uroczyście otwarto sądy królewsko-polskie, które na obszarze okupacji austro-węgierskiej przejęły zadania dotychczas działających sądów okupacyjnych oraz część właściwości sądów wojskowych9.

Nowa struktura sądownictwa przewidywała sądy pokoju, sądy okręgowe, sądy apelacyjne i kasacyjnie działający Sąd Najwyższy. Prezesi, sędziowie i prokuratorzy oraz podprokuratorzy sądów apelacyjnych byli mianowani przez Marszałka Koronnego na wniosek Dyrektora Departamentu Sprawiedliwości Tymczasowej Rady Stanu, a podprokuratorzy sądów okręgowych - przez Dyrektora Departamentu Sprawiedliwości na wniosek właściwego prokuratora ${ }^{10}$.

W Lublinie rozpoczął działalność nowy sąd apelacyjny i sąd okręgowy. Obszar właściwości królewsko-polskiego Sądu Okręgowego w Lublinie obejmował wtedy 10 powiatów: biłgorajski, chełmski, hrubieszowski, janowski, krasnostawski, lubartowski, lubelski, puławski, tomaszowski i zamojski. Utrzymano dotychczasowe siedziby i podział na okręgi sądów pokoju, a dotychczasowi sędziowie pokoju, którzy z dniem 1 września 1917 r. nie otrzymali nominacji na inne stanowiska, nadal tymczasowo sprawowali swoje obowiązki, ale

7 Szerzej na ten temat: W. Szwarc, Działania Tymczasowej Rady Stanu i Rady Regencyjnej na rzecz przejęcia cywilnego zarządu w Królestwie Polskim (1917-1918), [w:] Studia z historii państwa, prawa i idei, red. A. Korobowicz, H. Olszewski, Lublin 1997, s. 395-412; Prace Departamentów i Biur Tymczasowej Rady Stanu Królestwa Polskiego wykonane lub przygotowane przez czas jej istnienia, tj. od dnia 15 stycznia do 1 września 1917 r., Warszawa 1918, s. 37.

8 Dziennik Urzędowy Departamentu Sprawiedliwości Tymczasowej Rady Stanu (dalej: Dz.Urz. DS TRS) 1917, nr 1, dział II, s. 41 i dział III, s. 60-61, oraz nr 3, dział II, s. 98-101; Dziennik Rozporządzeń Generał-Gubernatora Warszawskiego 1917, nr 84, poz. 351; Dziennik Rozporządzeń c. i k. Zarządu Wojskowego w Polsce z 27 sierpnia 1917 r., cz. XIV, nr 71; Kalendarz Prawniczy na rok 1918, oprac. J. Fidler, Warszawa 1918, s. 3-8; ,Ziemia Lubelska” 1917, nr 430, s. 2 i nr 432, s. 2.

9 Dz.Urz. DS TRS 1917, nr 3, dział II, s. 100-101.

10 Art. 4 i art. 20-21 Przepisów tymczasowych o urządzeniu sądownictwa w Królestwie Polskim (Dz.Urz. DS TRS 1917, nr 1, dział I, poz. 1). 
już w charakterze urzędników królewsko-polskich ${ }^{11}$. Z czasem stopniowo rosła liczba mianowanych sędziów pokoju i malała grupa tymczasowo pozostawionych na tych urzędach.

Odznaką sędziego była zielona wstęga $\mathrm{z}$ emblematem sądów królewsko-polskich nałożona (pod marynarką) przez lewe ramię do prawego boku. Emblematem sądów był biały orzeł na wieńcu z pozłacanych liści dębowych umieszczony na tle amarantowym i wsparty na rzymskiej plakiecie z napisem „Sądy Królewsko-Polskie"12.

Na czele sądu pokoju w Zamościu, który „sprawował działalność w imieniu Korony Polskiej”, stał R. Jaśkiewicz. Sąd pokoju nadal orzekał w składzie mieszanym, tj. sędzia pokoju (jako przewodniczący) i dwóch ławników ${ }^{13}$.

Sądem odwoławczym od jego orzeczeń oraz sądem I instancji w sprawach poważniejszych był Sąd Okręgowy w Lublinie, który w dniu 17 grudnia 1917 r. rozstrzygnął kilkanaście spraw z tych terenów, odbywając pierwszą sesję wyjazdową w Zamościu. Już wtedy pojawiły się postulaty pochodzące od zamojskich organizacji społecznych i władz miejskich dotyczące utworzenia Sądu Okręgowego w Zamościu. Oficjalne uchwały podjęła Rada Miasta Zamościa i Powiatowy Komitet Ratunkowy, w czym niemałą rolę odegrali (zasiadający w tych gremiach) sędzia pokoju Romuald Jaśkiewicz i notariusz Teodor Kalinowski. Mimo zgłaszanych obaw co do utworzenia „odrębności” niebezpiecznych z uwagi na separatyzm ukraiński oraz faktu, że po pokoju brzeskim Zamość wraz z terenami dawnej Chełmszczyzny formalnie należał do Ukraińskiej Republiki Ludowej, w styczniu 1918 r. podjęto w Warszawie decyzję o utworzeniu nowego królewsko-polskiego Sądu Okręgowego z siedzibą w Zamościu ${ }^{14}$.

Sąd Okręgowy w Zamościu utworzono na mocy reskryptu Rady Regencyjnej Królestwa Polskiego z dnia 16 kwietnia 1918 r. Na podstawie uchwalonych w dniu 30 kwietnia 1918 r. przez Radę Ministrów przepisów wykonawczych do reskryptu

11 Dyzlokacja sądów Królewsko-Polskich (Dz.Urz. DS TRS 1917, nr 1, dział III, s. 60); Zarządzenie Marszałka Koronnego Tymczasowej Rady Stanu z 16 sierpnia 1917 r. (Dz.Urz. DS TRS 1917, nr 1, s. 61 i nr 3, s. 198); Z. Winnicki, Rada Regencyjna Królestwa Polskiego i jej organy (1917-1918), Wrocław 1991, s. 157-158.

12 Zarządzenie Dyrektora Departamentu Sprawiedliwości w przedmiocie odznak dla Królewsko-Polskich urzędników wymiaru sprawiedliwości (Dz.Urz. DS TRS 1917, nr 5, poz. 16, s. 240-241); „Gazeta Sądowa Warszawska” 1917, nr 42, s. 431; J. Litwin, Strój urzędowy (szarfa i toga) w sadownictwie polskim 1917-1965, „Czasopismo Prawno-Historyczne” 1966, nr 1, s. 216; J. Gudowski, Toga i biret - historia i współczesność urzędowego stroju sędziego, [w:] Ars et usus. Ksiega pamiatkowa ku czci Sędziego Stanisława Rudnickiego, Warszawa 2005, s. 153-154.

${ }_{13}$ Art. 5 Przepisów tymczasowych o urządzeniu sądownictwa w Królestwie Polskim (Dz.Urz. DS TRS 1917, nr 1, dział I, poz. 1).

14 Biblioteka Wojewódzka im. H. Łopacińskiego, rkps 1845, Prawo - Sądy i pożądane reformy w materiałach zebranych przez H. Wiercieńskiego, k. 84-85v, 223-225v; „Kronika powiatu zamojskiego" 1918, nr 3-4, s. 34-35. 
Rady Regencyjnej miał być on otwarty w dniu 1 czerwca 1918 r. Oba akty zostały jednocześnie ogłoszone w Dzienniku Praw z dnia 15 maja 1918 r. Nowy okręg zamojski został wyodrębniony z okręgu lubelskiego i obejmował swym obszarem właściwości powiaty: zamojski, biłgorajski, hrubieszowski i tomaszowski ${ }^{15}$.

Należące do Tymczasowej Rady Stanu uprawnienia nominacyjne na stanowiska sędziów i prokuratorów po jej rozwiązaniu przejęła Rada Regencyjna Królestwa Polskiego, wykonując je na wniosek utworzonego w styczniu 1918 r. Ministerstwa Sprawiedliwości. Z tego trybu wyłączono sędziów śledczych i sędziów pokoju, których samodzielnie mianował Minister Sprawiedliwości ${ }^{16}$.

Na samym początku pojawiły się trudności z obsadą personalną nowego sądu okręgowego. Pierwsze nominacje Rady Regencyjnej otrzymali: na stanowisko prezesa - Romuald Jaśkiewicz, na stanowiska sędziów - dr Jan Tenczyn i dr Teodor Kalinowski.

J. Tenczyn ukończył Uniwersytet Jagielloński, gdzie w 1899 r. otrzymał stopień doktora praw. Od 1902 r. pracował w sądownictwie galicyjskim, najpierw w okręgu krakowskim, a potem w Tarnowie na stanowisku sędziego powiatowego. Był aktywnym działaczem Towarzystwa Szkoły Ludowej i Sokoła. W sierpniu 1915 r. został przeniesiony do Królestwa Polskiego w celu organizacji sądownictwa w powiecie sandomierskim, a następnie służył w wyższych sądach okupacyjnych (w Trybunale w Radomiu). W dniu 1 września 1917 r. został sędzią śledczym VI rewiru przy SO w Lublinie z siedzibą w Zamościu, mimo że miał propozycję powrotu do Galicji i objęcia stanowiska radcy sądowego w Tarnowie.

T. Kalinowski ukończył Uniwersytet Warszawski w 1894 r. Po odbyciu stażu jako młodszy i starszy kandydat do posad sądowych, służył w sądownictwie rosyjskim jako sędzia śledczy, a następnie pełniący obowiązki sędziego śledczego do spraw szczególnej wagi w guberni płockiej. W 1903 r. został mianowany notariuszem w Zamościu. Zasiadał w składzie Rady Miasta Zamościa i aktywnie uczestniczył $\mathrm{w}$ działalności lokalnych organizacji dobroczynnych (m.in. jako skarbnik Komitetu Ratunkowego Miasta Zamościa). Niestety, po otrzymaniu nominacji odmówił przyjęcia urzędu sędziego, gdyż nie chciał porzucić posady notariusza ${ }^{17}$.

15 Dziennik Praw (dalej: Dz.P.) 1918, nr 5, poz. 11-12; Monitor Polski 1918, nr 47, s. 1; A. Bereza, Sąownictwo zamojskie - od czasów Ordynacji po współczesność, Zamość 2005, s. 41; M. Materniak-Pawłowska, Ustrój sądownictwa powszechnego w II Rzeczypospolitej, Poznań 2003, s. 80 .

16 Art. 33 dekretu Rady Regencyjnej o tymczasowej organizacji Władz Naczelnych w Królestwie Polskim (Dz.P. 1918, nr 1, poz. 1); W. Suleja, Tymczasowa Rada Stanu, Warszawa 1998, s. 72, 75, 180-181, 224-225; Z. Winnicki, op. cit., s. 41, 105, 117, 171.

17 Dziennik Urzędowy Ministerstwa Sprawiedliwości (dalej: Dz.Urz. MS) 1918, nr 10, s. 340; „Kronika powiatu zamojskiego” 1918, nr 3-4, s. 34-35; Kalendarz Lubelski na rok 1918, s. 101; 
Kolejne nominacje otrzymali: jeszcze w maju 1918 r. - adwokat przysięgły Jan Kopczyński, na początku czerwca zaś (a więc już po otwarciu sądu) sędzia śledczy przy SO w Radomiu dr Ferdynand Rydet ${ }^{18}$.

Uroczyste otwarcie Sądu Okręgowego w Zamościu w dniu 1 czerwca 1918 r. rozpoczęło się nabożeństwem w kolegiacie o godz. 9.00 rano. Uczestniczyli w nim nowo mianowani sędziowie i prokuratorzy, sędziowie śledczy i sędziowie pokoju okręgu zamojskiego, urzędnicy sądowi, notariusz Teodor Kalinowski, burmistrz Edward Stodółkiewicz, reprezentanci władz okupacyjnych z komendantem C. i K. Komendy Obwodowej (Powiatowej) płk. Julianem von Fischerem i licznie zgromadzona publiczność. Po nabożeństwie przedstawiciele magistratury sądowej udali się do lokalu na drugim piętrze Ratusza, który stał się tymczasową siedzibą Sądu Okręgowego, użyczoną bezpłatnie na ten cel przez władze miejskie. Były to pomieszczenia, które przed wojną służyły już celom sądowym jako siedziba zamojskiego zjazdu sędziów pokoju. W sali rozpraw sądowych prezes R. Jaśkiewicz oficjalnie odczytał reskrypt Rady Regencyjnej o utworzeniu Sądu Okręgowego w Zamościu i wydane na jego podstawie przepisy wykonawcze. Następnie prezes odebrał przysięgę od sędziów i urzędników sądowych, a prokurator okręgowy - od jednego dotychczas mianowanego podprokuratora ${ }^{19}$.

Jeszcze w tym samym roku na potrzeby nowo utworzonego sądu prezes R. Jaśkiewicz uzyskał od władz okupacyjnych w wyłączne posiadanie dawny pałac Zamoyskich położony przy ul. Ordynackiej (od 1927 r. - ul. Akademickiej). Gmach, w którym mieściły się wcześniej koszary rosyjskie, był zrujnowany, pozbawiony drzwi i okien. Natychmiast rozpoczęto prowizoryczne prace remontowe, lecz ich zakres nie pozwalał na szybką przeprowadzkę sądu do pomieszczeń pałacu ${ }^{20}$.

Etat utworzonego Sądu Okręgowego w Zamościu składał się z prezesa, czterech sędziów okręgowych i czterech sędziów śledczych (przeniesionych z etatu SO w Lublinie), a także prokuratora i trzech podprokuratorów. Obsługę sądu zapewniało 41 osób, w tym: dwóch sekretarzy, czterech podsekretarzy, dwudziestu dwóch kancelistów, sześciu woźnych i siedmiu posługaczy ${ }^{21}$. W skład sądu okręgowego zaliczano także ławników, którzy zasiadali w kompletach orzekających sądu okręgowego w sprawach karnych.

Pamiatnaja Kniżka Warszawskogo Sudiebnogo Okruga na 1915 god, s. 75; Sądownictwo cywilne w okupacji austryjacko-węgierskiej..., s. 31.

18 Dz.Urz. MS 1918, nr 10, s. 340 i nr 11, s. 364; „Kronika powiatu zamojskiego” 1918, nr 9 , s. 39; APL, SAL, SZO, nr 1, sygn. 78, k. 5.

19 „Kronika powiatu zamojskiego” 1918, nr 5-6, s. 87.

20 APL, SAL, SZO, nr 1, sygn. 77, k. 22; A. Kędziora, Encyklopedia Miasta Zamościa, Chełm 2000, s. 278.

21 Art. 2 Przepisów wykonawczych do Reskryptu Rady Regencyjnej Królestwa Polskiego w przedmiocie utworzenia Królewsko-Polskiego Sądu Okręgowego w Zamościu (Dz.P. 1918, nr 5, poz. 12); Dziennik Urzędowy Królewsko-Polskiego Ministerstwa Sprawiedliwości (dalej: Dz.Urz. KP MS) 1918, nr 11, poz. 1, s. 353. 
Do pierwszego składu Sądu Okręgowego w Zamościu weszli: prezes Romuald Jaśkiewicz i sędziowie: J. Kopczyński, J. Tenczyn i F. Rydet oraz przeniesiony z SO w Łodzi Franciszek Duralski, który następnie objął stanowisko wiceprezesa. Ostatni z nich miał za sobą staż służby na stanowisku sędziego powiatowego w Kielcach pod okupacją austriacką 22 .

Funkcję prezesa sprawował R. Jaśkiewicz (1857-1930), na którego barkach spoczął ciężar organizacji sądu. Był absolwentem Uniwersytetu Warszawskiego i zamojskim adwokatem przysięgłym z długą praktyką (od 28 czerwca 1883 r.). Aktywnie uczestniczył w życiu społecznym Zamościa i okolicy, m.in. jako prezes Koła Polskiej Macierzy Szkolnej, Komitetu Ratunkowego Miasta Zamościa, Resursy oraz Komitetu Powszechnych Wykładów Lwowskiego Uniwersytetu i Politechniki, a także członek wydziału wykonawczego okręgowej Rady Szkolnej i prezes sekcji organizacyjnej Powiatowego Koła Straży Kresowej. Zasiadał również w Radzie Miasta Zamościa. Od września 1915 r. był obywatelskim sędzią pokoju w Zamościu, następnie zaś kolejno: sędzią pokoju w systemie sądownictwa okupacyjnego, królewsko-polskim sędzią pokoju, a od 11 maja 1918 r. - prezesem SO w Zamościu. Jako sędzia był wzorem do naśladowania dla młodszych pracowników, imponował im „hartem woli, sumiennością i przedziwnym darem inicjatywy". Nie tylko kierował sądem, ale też - $\mathrm{z}$ uwagi na niewielką obsadę - stale orzekał. Pracował niemal codziennie od godz. 6.00 rano do godz. 1.00 lub $2.00 \mathrm{w}$ nocy, z przerwą na obiad i posiłek wieczorny. Cieszył się także dużym poważaniem w Ministerstwie Sprawiedliwości przez cały okres piastowania funkcji prezesa. W uznaniu zasług położonych dla Rzeczypospolitej na polu organizacji sądownictwa został w $1923 \mathrm{r}$. odznaczony Krzyżem Komandorskim Orderu Odrodzenia Polski. Na stanowisku prezesa pozostał aż do przeniesienia na podstawie postanowienia Ministra Sprawiedliwości z dnia 25 lutego 1930 r. w stan spoczynku z dniem 31 marca 1930 r. Następnie wyjechał do Ostrowca Świętokrzyskiego, aby objąć posadę notariusza przy wydziale hipotecznym Sądu Powiatowego w Opatowie. Po kilku tygodniach zmarł na serce w dniu 15 maja 1930 r. w Ostrowcu. Jego pogrzeb w Zamościu był wielkim hołdem dla człowieka, który prawie całe życie związał z tym miastem. Dla uczczenia jego pamięci skwer przed pałacem Zamoyskich został nazwany jego imieniem ${ }^{23}$.

22 Dz.Urz. MS 1918, nr 10, s. 340, 346 i nr 11, s. 364; Dz.Urz. MS 1919, nr 5, s. 177; „Kronika powiatu zamojskiego" 1918, $\mathrm{nr}$ 11, s. 64; Sądownictwo cywilne w okupacji austryjacko-wegierskiej..., s. 31.

${ }^{23}$ APL, SAL, SZO, nr 1, sygn. 77, k. 22-23, 30, 54-55, 72-73-75, 80-81; ,Kronika powiatu zamojskiego" 1918, nr 3-4, s. 34; K. Czubara, Dawniej w Zamościu. O skarbach, duchach i czartach, sławnych generałach, poetach, wizytach dostojnych gości, wielkich balach, pojedynkach i kurtyzanach, Zamość 2005, s. 92; „Ruch Służbowy. Dodatek do Dziennika Urzędowego Ministerstwa Sprawiedliwości” (dalej: RS) 1930, nr 8, s. 101; A. Kędziora, op. cit., s. 136-137. 
Przy Sądzie Okręgowym w Zamościu urzędowało także czterech rewirowych sędziów śledczych. Siedziby ich biur znajdowały się w miastach powiatowych okręgu zamojskiego. W Biłgoraju urzędował Włodzimierz Aleksander Adloff, w Hrubieszowie - Stanisław Reiss, w Tomaszowie - Witold Zasztowt, a w Zamościu - Józef Terlecki²4. Później pojawił się jeszcze dodatkowo zapasowy sędzia śledczy. Do ich zadań należało prowadzenie śledztwa wstępnego. Zadania te w sytuacji, gdy sędzia śledczy nie był w stanie przeprowadzić tych czynności mogli wykonywać także sędziowie pokoju w obrębie swoich okręgów sądowych na żądanie urzędu prokuratorskiego lub sądu okręgowego ${ }^{25}$.

Urząd prokuratora przy Sądzie Okręgowym w Zamościu objął sędzia śledczy przy SO w Kielcach Józef Gałęziewicz, mianowany na to stanowisko postanowieniem Rady Regencyjnej z dnia 18 maja 1918 r. Po kilku miesiącach został przeniesiony do Lublina, a jego następcą został Włodzimierz Skalski. Ten również urzędował krótko, po czym przeniesiono go na stanowisko prokuratora przy SO w Kielcach ${ }^{26}$. Prokuratorowi okręgowemu podlegało w urzędzie trzech podprokuratorów. Pierwsze nominacje na te stanowiska otrzymali: Wincenty Krajewski i Stanisław Bielenia, nieco później zaś ostatni wolny etat objął Józef Ignacy Parczewski ${ }^{27}$.

W dniu 1 czerwca 1918 r. na obszarze nowo utworzonego okręgu zamojskiego funkcjonowało 19 sądów pokoju z siedzibami w Zamościu (okręg miejski i wiejski), Szczebrzeszynie, Krasnobrodzie, Frampolu, Udryczach, Tomaszowie (okręg miejski i wiejski), Krynicach, Oszczowie, Tyszowcach, Hrubieszowie (okręg miejski i wiejski), Grabowcu, Mirczu, Biłgoraju, Józefowie, Krzeszowie i Tarnogrodzie ${ }^{28}$. Kierujący sądem pokoju sędzia pokoju nie musiał mieć wykształcenia prawniczego, ale wtedy miał obowiązek legitymować się praktyczną znajomością obowiązującego prawa.

W Zamościu działały dwa sądy pokoju obejmujące tzw. okręg miejski i okręg wiejski. W skład sądu pokoju w okręgu miejskim wchodził sędzia, który miał do pomocy personel złożony z sekretarza, kancelisty i woźnego, natomiast w sądzie pokoju w okręgu wiejskim przewidziano dodatkowo stanowisko sekretarza hipo-

24 „Kronika powiatu zamojskiego” 1918, nr 11, s. 65; Dz.Urz. MS 1918, nr 11 s. 364.

25 Przepisy tymczasowe o udziale sędziów pokoju i sekretarzy sędziów pokoju w prowadzeniu śledztwa wstępnego uchwalone przez Komisję Przejściową Tymczasowej Rady Stanu Królestwa Polskiego w dniu 25 września 1917 r. (Dz.Urz. DS. TRS 1917, nr 6, dział I, s. 245-246).

26 Dz.Urz. KP MS 1918, nr 10, s. 340 i nr 11, s. 363 i 366; Dz.Urz. MS 1919, nr 2, s. 95; „Kronika powiatu zamojskiego” 1918, nr 9, s. 39 i nr 11, s. 64.

27 „Kronika powiatu zamojskiego” 1918, nr 11, s. 65; Dz.Urz. MS 1918, nr 9, s. 312, nr 10, s. 343 i nr 13, s. 408.

28 Art. 3 Przepisów wykonawczych do Reskryptu Rady Regencyjnej Królestwa Polskiego w przedmiocie utworzenia Królewsko-Polskiego Sądu Okręgowego w Zamościu (Dz.P. 1918, nr 5, poz. 12). 
tecznego dla czynności związanych z hipoteką powiatowąa ${ }^{29}$. Na czele zamojskich sądów pokoju stali wtedy mianowani przez Ministra Sprawiedliwości: dr Zygmunt Kostkiewicz (w okręgu miejskim) i Adam Ignacy Sajkiewicz (w okręgu wiejskim) ${ }^{30}$.

Sądem odwoławczym od orzeczeń sądów pokoju z okręgu zamojskiego, a zarazem sądem I instancji w poważniejszych sprawach cywilnych i karnych z tego obszaru był Sąd Okręgowy w Zamościu. Rozpoznawał on w I instancji sprawy cywilne i karne, które wpłynęły po dniu 1 czerwca 1918 r., a także sprawy cywilne z obszaru obejmującego nowy okręg, które przed dniem 1 czerwca 1918 r. wpłynęły do Sądu Okręgowego w Lublinie i zostały przeniesione do Sądu Okręgowego w Zamościu na zgodny wniosek stron złożony przed dniem 1 lipca 1918 r., oraz sprawy karne, które przed dniem 1 czerwca 1918 r. wpłynęły do Sądu Okręgowego w Lublinie, o ile nie zostały w nim już przeprowadzone lub nie został w nim wyznaczony termin rozprawy głównej ${ }^{31}$.

Sąd Okręgowy w Zamościu orzekał w składzie zawodowym trzech sędziów w sprawach cywilnych oraz w składzie mieszanym: sędzia (jako przewodniczący) i dwóch ławników w sprawach karnych i handlowych. Sądem odwoławczym od jego orzeczeń wydanych w I instancji był Sąd Apelacyjny w Lublinie ${ }^{32}$.

Sąd Okręgowy w Zamościu sprawował również nadzór nad sędziami śledczymi, komornikami, notariuszami, adwokatami przysięgłymi i obrońcami prywatnymi wykonującymi swoje czynności zawodowe na obszarze okręgu zamojskiego. Natomiast czynności hipoteczne z tego obszaru należały tymczasowo (stan ten uległ przedłużeniu do 1 października 1923 r.) do właściwości wydziału hipotecznego Sądu Okręgowego w Lublinie ${ }^{33}$.

Kilka miesięcy po otwarciu Sądu Okręgowego w Zamościu, w następstwie korzystnego splotu wydarzeń oraz aktywności społecznej, zaczęły powstawać zręby niepodległego Państwa Polskiego. W dniach 1-2 listopada 1918 r. władzę w Zamościu przejęły oddziały polskie z miejscowego garnizonu wojskowego wsparte przez członków Polskiej Organizacji Wojskowej. Ważną rolę w tych wydarzeniach odegrał m.in. sędzia pokoju Adam Sajkiewicz, który jako członek Powiatowego Komitetu Ratunkowego podpisał odezwę o przejęciu władzy w mie-

29 Dz.Urz. KP MS 1918, nr 11, poz. 1, s. 353.

30 Dz.Urz. KP MS 1918, nr 10, s. 365 i nr 12, s. 387.

31 Art. 4 i 5 Przepisów wykonawczych do Reskryptu Rady Regencyjnej Królestwa Polskiego w przedmiocie utworzenia Królewsko-Polskiego Sądu Okręgowego w Zamościu (Dz.P. 1918, nr 5, poz. 12).

32 Art. 5 i 7-8 Przepisów tymczasowych o urządzeniu sądownictwa w Królestwie Polskim (Dz.Urz. DS TRS 1917, nr 1, dział I, poz. 1).

33 Art. 4 i 5 Przepisów wykonawczych do Reskryptu Rady Regencyjnej Królestwa Polskiego w przedmiocie utworzenia Królewsko-Polskiego Sądu Okręgowego w Zamościu (Dz.P. 1918, nr 5, poz. 12). 
ście. Krótko nawet piastował stanowisko starosty zamojskiego w ostatnich dniach rządów Rady Regencyjnej, co świadczyło o szybkim rozpadzie austriackich władz okupacyjnych ${ }^{34}$. Niedługo potem, a formalnie na podstawie dekretu Tymczasowego Naczelnika Państwa o najwyższej władzy reprezentacyjnej Republiki Polskiej z dnia 22 listopada 1918 r., sądy zaczęły wydawać wyroki „w imieniu Republiki Polskiej”, sędziowie zaś używali dotychczasowych odznak ze zmienionym napisem na plakiecie emblematu: „Sądy Rzeczypospolitej Polskiej”35.

Po instalacji władz polskich w Zamościu prezes R. Jaśkiewicz, z uwagi na duże kłopoty lokalowe w mieście, zmuszony był do podjęcia wielu zabiegów, aby w remontowanym wtedy pałacu Zamoyskich nie zostały umieszczone organy administracji. Jednocześnie uzyskał kredyty na odbudowę pałacu dzięki skutecznym zabiegom w Ministerstwie Robót Publicznych, Ministerstwie Kultury i Sztuki oraz Ministerstwie Skarbu, a następnie osobiście uczestniczył w sporządzaniu kosztorysów prac i protokołów z ich wykonania. W wyniku przeprowadzonych prac pałac Zamoyskich został przystosowany do potrzeb wymiaru sprawiedliwości i jednolicie umeblowany, a od 1920 r. stał się nową siedzibą sądu okręgowego i urzędu prokuratorskiego. Część pomieszczeń zajmowała jednak żandarmeria (do 1922 r.) i obsługa administracyjna sejmiku. Odremontowano także boczne i wewnętrzne skrzydła pałacu, w których zostały urządzone mieszkania dla sędziów i woźnych sądowych. W południowym skrzydle pałacu umieszczono również sąd pokoju, a w północnym - kancelarię notarialną ${ }^{36}$.

W 1919 r. nastąpiły zmiany kadrowe w Sądzie Okręgowym w Zamościu, które były na tyle poważne, że spowodowały kłopoty z ustaleniem kompletów orzekających. Sędzia J. Kopczyński przeszedł na służbę do Prezydium Rady Ministrów, a później został sędzią i prezesem Najwyższego Trybunału Administracyjnego; wiceprezes F. Duralski został radcą ministerialnym, a później awansował na stanowisko dyrektora SO w Poznaniu; sędzia J. Tenczyn został przeniesiony do SO w Warszawie; w listopadzie zaś zwolniono z pełnienia obowiązków sędziego F. Rydeta na okres powołania do służby wojskowej. Nigdy już nie powrócił do Zamościa. W czasie wojny, będąc w randze majora, orzekał w sądzie Dowództwa Okręgu Generalnego w Warszawie, a następnie przeszedł do adwokatury i praktykował w Stanisławowie ${ }^{37}$.

34 K. Radziejewski, op. cit., s. 90; B. Sawa, Była sobie Hyża, „Tygodnik Zamojski” 1993, $\mathrm{nr}$ 12, s. 11; P. Wróbel, Listopadowe dni - 1918. Kalendarium narodzin II Rzeczypospolitej, Warszawa 2018 , s. 22, 35 .

35 Dekret Tymczasowego Naczelnika Państwa o najwyższej władzy reprezentacyjnej Republiki Polskiej z dnia 22 listopada 1918 r. (Dziennik Praw Państwa Polskiego 1918, nr 17, poz. 41).

36 APL, SAL, SZO, nr 1, sygn. 77, k. 22-24; A. Kędziora, op. cit., s. 278.

37 Dz.Urz. MS 1919, nr 7, s. 273 i nr 9, s. 310; Dz.Urz. MS 1920, nr 1, s. 13; Kalendarz Informator Sadowy na 1938 rok, oprac. J. Kirkiczenko, M. Kraczkiewicz, K. Rudzisz, Warszawa 1938, s. 326; APL, SAL, SZO, nr 1, sygn. 78, k. 17-19; AAN, Prezydium Rady Ministrów, cz. VIII, Karty 
Jednocześnie na początku 1919 r. nominacje na stanowiska sędziów okręgowych w Zamościu otrzymali: adwokat dr Zdzisław Szwaykowski (otrzymał też nominację na stanowisko sędziego śledczego w Zamościu, którego nie objął) i sędzia śledczy przy SO w Zamościu urzędujący w Zamościu Józef Terlecki, a nieco później sędzia pokoju z Hrubieszowa Adolf Gatnikiewicz ${ }^{38}$.

Byli oni prawnikami o proweniencji galicyjskiej, dysponowali doświadczeniem sądowym, lecz bez dobrej znajomości prawa miejscowego. Z. Szwaykowski przed wybuchem wojny pracował w sądownictwie jako auskultant przy Sądzie Krajowym w Krakowie i Sądzie Obwodowym w Kołomyi, a następnie praktykował jako adwokat w Rzeszowie. W czasie wojny służył jako porucznik audytor przy sądzie wojskowym w Zamościu ${ }^{39}$. J. Terlecki służył jako auskultant w Sądzie Obwodowym w Tarnopolu, a potem był sędzią powiatowym w Żurawnie i Lipsku. W 1916 r. został przeniesiony do austriackiego sądownictwa okupacyjnego na terenie Królestwa Polskiego, gdzie objął funkcję przewodniczącego Sądu Obwodowego (Powiatowego) w Tomaszowie, a w sądownictwie królewsko-polskim kolejno piastował stanowiska: sędziego pokoju w Tomaszowie, sędziego śledczego dla powiatu tomaszowskiego, natomiast po utworzeniu Sądu Okręgowego w Zamościu - sędziego śledczego dla powiatu zamojskiego ${ }^{40}$. Podobną ścieżkę kariery zawodowej miał A. Gatnikiewicz, dotychczasowy sędzia powiatowy w Szczercu. Przeniesiony do austriackiego sądownictwa okupacyjnego na terenie Królestwa Polskiego, urzędował na stanowisku przewodniczącego Sądu Obwodowego (Powiatowego) w Chełmie, a w sądownictwie królewsko-polskim orzekał jako sędzia pokoju w Hrubieszowie ${ }^{41}$. Niestety, na stanowisku sędziego okręgowego pozostał z nich najkrócej, bo tylko do 1920 r., kiedy przeszedł do sądownictwa polskiego organizowanego w byłej Dzielnicy Pruskiej ${ }^{42}$.

kwalifikacyjne 21, nfol.; Dziennik Urzędowy Ministerstwa Byłej Dzielnicy Pruskiej 1920, nr 63, s. 1014.

38 Dz.Urz. MS 1919, nr 7, s. 266, 268 i nr 9, s. 309.

39 Archiwum Akt Nowych (dalej: AAN), Ministerstwo Sprawiedliwości (dalej: MS), Spis zdawczo-odbiorczy (dalej: SZO) 13/1899, Akta osobowe Zdzisława Szwaykowskiego, k. 3-4, $16-17$.

40 AAN, MS, SZO 13/1924, Akta osobowe Józefa Terleckiego, k. 4, 34-35, 39-40; Dz.Urz. MS 1918, nr 7, s. 272 i nr 10, s. 341; Sąownictwo cywilne w okupacji austryjacko-węgierskiej ..., s. 32.

${ }^{41}$ Ibidem, s. 31; Szematyzm Królestwa Galicyi i Lodomeryi z Wielkim Księstwem Krakowskiem na rok 1914, Lwów 1914, s. 113; Dz.Urz. KP MS 1918, nr 7, s. 272.

42 Został sędzią SO w Ostrowie, a następnie w Poznaniu, po czym w 1926 r. awansował na stanowisko sędziego SA w Poznaniu. W dniu 25 czerwca 1927 r. został mianowany sędzią V Izby Sądu Najwyższego, lecz już w dniu 3 lutego 1928 r. powrócił na swoje dotychczasowe stanowisko, na którym służył do 1935 r. Zob. Dz.Urz. MS 1927, nr 17, s. 353; Dz.Urz. MS 1928, nr 7, s. 124; Dziennik Urzędowy Ministerstwa Byłej Dzielnicy Pruskiej 1920, nr 63, s. 1015; „Dziennik Bydgoski” 1926, nr 197, s. 9A. Zob. także: A. Bereza, Sad Najwyższy 1917-2017. Prezesi, sędziowie i prokuratorzy Sadu Najwyższego, Warszawa 2017, s. 116; Kalendarz Informator Sadowy na 1935 rok, oprac. J. Kirkiczenko, M. Kraczkiewicz, K. Rudzisz, Warszawa 1935, s. 143. 
Zapewniało to niewielką obsadę Sądu Okręgowego, która pozwalała na jego funkcjonowanie, mimo że Zamość i powiat zamojski od początku marca do końca maja 1919 r. był ustanowiony obszarem wojennym.

W drugiej połowie 1919 r. nominacje na stanowiska zamojskich sędziów okręgowych otrzymali: podprokurator zamojski Józef Ignacy Parczewski (w następnym roku został na własną prośbę zwolniony), były adwokat przysięgły w Bielcach w dawnej guberni besarabskiej Mieczysław Czyżewski oraz sędzia pokoju w Krasnymstawie Henryk Gustaw Gisges ${ }^{43}$. Ostatni z nich był absolwentem Uniwersytetu Warszawskiego i legitymował się doświadczeniem z pracy w rosyjskim sądownictwie pokojowym, podobnie jak inni przedstawiciele rodziny Gisgesów. Od 1896 r. był sekretarzem wydziału hipotecznego u boku sędziego pokoju w Biłgoraju, a w latach 1899-1915 piastował to stanowisko u boku sędziego pokoju w Zamościu. Był postacią znaną w środowisku zamojskim jako filantrop i działacz społeczny. Zasiadał w Radzie Miasta Zamościa oraz był współzałożycielem m.in. Towarzystwa Muzyczno-Dramatycznego i Towarzystwa Pomocy Niezamożnej Młodzieży. Z chwilą uruchomienia sądów królewsko-polskich został mianowany sędzią pokoju w Krasnymstawie ${ }^{44}$.

Zarówno M. Czyżewski, jak i H.G. Gisges długo orzekali w Sądzie Okręgowym w Zamościu. Pierwszy z nich urzędował aż do śmierci w dniu 6 grudnia 1927 r., drugi zaś do momentu przejścia w stan spoczynku z dniem 30 czerwca 1930 r. ${ }^{45}$

Sąd wewnętrznie był podzielony na dwa wydziały: cywilny i karny (kolejny wydział - hipoteczny - utworzono dopiero od 1 października 1923 r. $)^{46}$.

W styczniu 1920 r. obsada etatowa Sądu Okręgowego w Zamościu składała się z prezesa, wiceprezesa i siedmiu sędziów, lecz nie wszystkie stanowiska były obsadzone. Od października 1919 r. wakowało m.in. stanowisko wiceprezesa, gdyż kandydaci z innych sądów okręgowych, którym proponowano tę posadę, nie zgadzali się na przeniesienie służbowe (nawet połączone $\mathrm{z}$ awansem), powołując się na różne przyczyny osobiste. Dopiero w kwietniu 1920 r. wiceprezesem został sędzia Z. Szwaykowski ${ }^{47}$.

Przy Sądzie Okręgowym w Zamościu urzędowało nadal czterech rewirowych sędziów śledczych z siedzibami w miastach powiatowych oraz zapasowy sędzia

43 Dz.Urz. MS 1919, nr 9, s. 309; Dz.Urz. MS 1920, nr 2, s. 32 i nr 5-6, s. 127.

44 Pamiatnaja Kniżka Warszawskogo Sudiebnogo Okruga na 1897 g., Warszawa 1897, s. 53; Pamiatnaja Knizka Warszawskogo Sudiebnogo Okruga na 1900 g., Warszwa 1900, s. 71; Pamiatnaja Knizkka Warszawskogo Sudiebnogo Okruga na 1915 g., s. 81; Pamjatnaja Kniżka Lublinskoj Gubernii na 1899 g., s. 189; Pamjatnaja Kniżka Lublinskoj Gubernii na 1900 g., s.190; Dz.Urz. DS TRS 1917, nr 5, s. 233; A. Bereza, Sądownictwo pokojowe w guberni lubelskiej na tle Królestwa Polskiego (1876-1915), Lublin 2004, s. 246-247, 344.

45 Dz.Urz. MS 1928, nr 4, s. 88; RS 1930, nr 11, s. 130.

46 Rozporządzenie RM z 17 maja 1923 r. o utworzeniu wydziału hipotecznego przy sądzie okręgowym w Zamościu (Dz.U. nr 56, poz. 399).

47 AAN, MS, SZO 13/1899, Akta osobowe Zdzisława Szwaykowskiego, k. 4; APL, SAL, SZO, nr 1, sygn. 2085, k. 5-6; Dz.Urz. MS 1921, nr 1, s. 15. 
śledczy. W grupie tej w 1919 r. miał miejsce spory ruch kadrowy. Stanowiska te, niejednokrotnie będące początkiem kariery w wymiarze sprawiedliwości, były często obsadzane przez aplikantów przy SA w Lublinie. Na zwolnione stanowisko sędziego śledczego w Tomaszowie mianowano aplikanta Aleksandra Mieczysława Surewicza, a po jego przeniesieniu na to samo stanowisko w SO w Białymstoku mianowano aplikanta Ignacego Brusznickiego, który w 1920 r. został podprokuratorem przy SO w Kielcach ${ }^{48}$. Po mianowaniu J. Terleckiego na stanowisko sędziego okręgowego w Zamościu rewirowym sędzią śledczym w Zamościu został Tomasz Wilczak, który po kilku miesiącach został przeniesiony na stanowisko zapasowego sędziego śledczego. Na zwolnione stanowisko mianowano jeszcze w 1919 r. aplikantów: Stefana Stankiewicza (który zaraz poprosił o zwolnienie) i Stanisława Matkowskiego ${ }^{49}$. Ostatni z nich służył na stanowisku rewirowego sędziego śledczego w Zamościu bardzo długo, jak na ówczesne warunki, gdyż do lutego 1928 r. Został wtedy mianowany sędzią okręgowym w Zamościu ${ }^{50}$.

Prokuratorem okręgowym pod koniec 1918 r. był jeszcze Włodzimierz Skalski, lecz już od stycznia 1919 r. stanowisko to objął dotychczasowy (od 1 września 1917 r.) podprokurator okręgowy w Lublinie Józef Skolimowski. Urzędował aż do maja 1926 r., po czym został przeniesiony na takie samo stanowisko do SO w Łucku, a w 1932 r. - do SO w Lublinie ${ }^{51}$. W Urzędzie Prokuratorskim podlegało im nadal trzech (później czterech) podprokuratorów. Z pierwszej obsady tych stanowisk odszedł J.I. Parczewski, awansowany w 1919 r. na stanowisko sędziego okręgowego, a zwolniony przez niego etat obsadzono dopiero $\mathrm{w}$ roku następnym.

$\mathrm{Z}$ chwilą powstania niepodległego Państwa Polskiego zachowano dotychczasowe okręgi sądów pokoju na podstawie dekretu z 7 lutego 1919 r. w przedmiocie dyslokacji sądów ${ }^{52}$.

W Zamościu nadal funkcjonowały dwa sądy pokoju - odrębnie dla okręgu miejskiego i okręgu wiejskiego. Pod koniec 1919 r. z urzędu sędziego pokoju w okręgu miejskim został zwolniony Z. Kostkiewicz, który nie orzekał już od dłuższego czasu, a ze stanowiska sędziego pokoju w okręgu wiejskim odszedł A. Sajkiewicz ${ }^{53}$. W ich miejsce pojawili się: w okręgu miejskim od 26 kwietnia 1920 r. Stanisław Bielenia (podprokurator przy SO w Zamościu), a w okręgu wiej-

48 Dz.Urz. MS 1919, nr 2, s. 91 i nr 7, s. 266; Dz.Urz. MS 1920, nr 1, s. 11, 14 i nr 3, s. 64.

49 Dz.Urz. MS 1919, nr 2, s. 91 i nr 9, s. 311, 317.

50 Dz.Urz. MS 1928, nr 9, s. 140.

51 Dz.Urz. DS TRS 1917, nr 4, s. 231; Dz.Urz. MS 1919, nr 2, s. 91; Dz.Urz. MS 1926, nr 16, s. 338.

52 Art. 1 dekretu z 7 lutego 1919 r. w przedmiocie dyzlokacji sądów (Dziennik Praw Państwa Polskiego 1919, nr 14, poz. 170).

53 Dz.Urz. MS 1920, nr 1, s. 15 i nr 4, s. 88. 
skim od 24 listopada 1919 r. Zygmunt Zawadzki (sędzia pokoju w Udryczach) ${ }^{54}$. S. Bielenia orzekał do 5 stycznia 1921 r., kiedy został mianowany sędzią SO w Zamościu ${ }^{55}$, natomiast Z. Zawadzki - do 24 listopada 1924 r., po czym objął posadę notariusza w Hrubieszowie ${ }^{56}$.

Mianowanie do służby państwowej w sądownictwie w tym okresie zazwyczaj było poprzedzone zasięgnięciem opinii o kwalifikacjach „moralnych i umysłowych" od osób, na które kandydat na stanowisko sędziego powoływał się w swoim wniosku. Niekiedy potwierdzenie posiadania wykształcenia prawniczego (zwłaszcza od tych, którzy ukończyli dawne uniwersytety rosyjskie) oraz odbycia odpowiedniej praktyki adwokackiej wystarczającej do objęcia urzędu sędziego opierało się na ustnych zeznaniach świadków i referencjach osób wskazanych w podaniach o przyjęcie do służby.

Na stanowiska niższe (szczególnie sędziów śledczych, a niekiedy sędziów pokoju) kierowano już w tym okresie aplikantów sądowych pozostających przy Sądzie Apelacyjnym w Lublinie. Ruch kadrowy na tych stanowiskach był stosunkowo duży, co wiązało się z płynnością obsady na szczeblu sądów najniższej instancji na skutek odpływu sędziów do adwokatury. Tendencja ta powoli malała, a została zahamowana dopiero po reformie sądowej w 1929 r. Jednocześnie niektórzy zasłużeni sędziowie, po zakończeniu służby sądowej i przejściu w stan spoczynku, otrzymywali na swój wniosek posady notariusza czy pisarza hipotecznego, które - z uwagi na osiągane dochody - budzily duże zainteresowanie. Spośród przedstawionych sędziów i prokuratorów posady notariusza otrzymali nieliczni, m.in. prezes R. Jaśkiewicz (w kwietniu 1930 r. w Opatowie), sędzia pokoju Z. Zawadzki (w listopadzie 1924 r. w Hrubieszowie), sędzia okręgowy J. Terlecki (w kwietniu 1925 r. w Krotoszynie), prokurator J. Skolimowski (w czerwcu 1938 r. w Lublinie) ${ }^{57}$.

\section{BIBLIOGRAFIA}

\section{Archiwa}

1. Archiwum Akt Nowych, Ministerstwo Sprawiedliwości, Spis zdawczo-odbiorczy:

- sygn. 13/612, Akta osobowe Zygmunta Zawadzkiego,

- sygn. 13/1899, Akta osobowe Zdzisława Szwaykowskiego,

- sygn. 13/1924, Akta osobowe Józefa Terleckiego.

54 AAN, MS, SZO 13/612, Akta osobowe Zygmunta Zawadzkiego, k. 5; Dz.Urz. MS 1920, nr 1, s. 14 i nr 4, s. 88; Dz.Urz. MS 1921, nr 1, s. 17.

55 APL, SAL, SZO, nr 1, sygn. 80, k. 10, 17-18, 28, 30; Dz.Urz. MS 1921, nr 5, s. 93.

56 Dz.Urz. MS 1922, nr 23, s. 433; Dz.Urz. MS 1924, nr 24, s. 597; AAN, MS, SZO 13/612, Akta osobowe Zygmunta Zawadzkiego, k. 5-6.

57 Dz.Urz. MS 1924, nr 23, s. 597; Dz.Urz. MS 1938, nr 7, s. 107; J. Mazurkiewicz, L. Policha, Dzieje sadownictwa lubelskiego w latach 1915-1944 (maszynopis), s. 36-37; Z. Klukowski Zamojszczyzna 1918-1959, Warszawa 2017, s. 148; AAN, MS, SZO 13/1924, Akta osobowe Józefa Terleckiego, k. 208. 
2. Archiwum Akt Nowych, Prezydium Rady Ministrów, cz. VIII, Karty kwalifikacyjne 21.

3. Archiwum Państwowe w Lublinie, Sąd Apelacyjny w Lublinie 1917-1951, Spis zdawczo-odbiorczy, nr 1, sygn. 77, 78, 80, 104, 2085.

4. Biblioteka Wojewódzka im. H. Łopacińskiego:

- rkps 1845, Prawo - Sądy i pożądane reformy w materiałach zebranych przez H. Wiercieńskiego.

\section{Czasopisma}

„Dziennik Bydgoski” 1926.

„Gazeta Sądowa Warszawska” 1917.

„Głos Lubelski” 1922.

„Kronika powiatu zamojskiego” 1918.

„Ziemia Lubelska” 1917.

\section{Zbiory urzędowe i informatory}

Dziennik Praw 1918.

Dziennik Praw Państwa Polskiego 1918, 1919.

Dziennik Rozporządzeń c. i k. Zarządu Wojskowego w Polsce 1917, cz. XIV.

Dziennik Rozporządzeń Generał-Gubernatora Warszawskiego 1917.

Dziennik Rozporządzeń Zarządu Wojskowego 1916.

Dziennik Urzędowy Departamentu Sprawiedliwości Tymczasowej Rady Stanu 1917.

Dziennik Urzędowy Królewsko-Polskiego Ministerstwa Sprawiedliwości 1918.

Dziennik Urzędowy Ministerstwa Byłej Dzielnicy Pruskiej 1920.

Dziennik Urzędowy Ministerstwa Sprawiedliwości 1918, 1919, 1920, 1921, 1922, 1924, 1926, 1927, 1928, 1938.

Dziennik Ustaw 1923.

Kalendarz Informator Sądowy na 1935 rok, oprac. J. Kirkiczenko, M. Kraczkiewicz, K. Rudzisz, Warszawa 1935.

Kalendarz Informator Sądowy na 1938 rok, oprac. J. Kirkiczenko, M. Kraczkiewicz, K. Rudzisz, Warszawa 1938.

Kalendarz Lubelski na rok 1918.

Kalendarz Prawniczy na rok 1918, oprac. J. Fidler, Warszawa 1918.

Monitor Polski 1918.

Pamjatnaja Kniżka Lublinskoj Gubernii na $1899 \mathrm{~g}$.

Pamjatnaja Knizka Lublinskoj Gubernii na 1900 g.

Pamiatnaja Kniżka Warszawskogo Sudiebnogo Okruga na 1897 g., Warszawa 1897.

Pamiatnaja Kniżka Warszawskogo Sudiebnogo Okruga na 1900 g., Warszwa 1900.

Pamiatnaja Kniżka Warszawskogo Sudiebnogo Okruga na 1915 g., Warszawa 1915.

Prace Departamentów i Biur Tymczasowej Rady Stanu Królestwa Polskiego wykonane lub przygotowane przez czas jej istnienia, tj. od dnia 15 stycznia do 1 września 1917 r., Warszawa 1918.

„Ruch Służbowy. Dodatek do Dziennika Urzędowego Ministerstwa Sprawiedliwości” 1930.

Sąownictwo cywilne w okupacji austryjacko-wegierskiej 1915-1917, Lublin 1918.

Schematismus des k.u.k. Militär-General-Gouvernements für das österreichisch-ungarische Okkupationsgebiet in Polen, Lublin [b.r.w.].

Szematyzm Królestwa Galicyi i Lodomeryi z Wielkim Księstwem Krakowskiem na rok 1914, Lwów 1914.

„Verordnungsblatt für das Generalgouvernement Warschau“ 1916. 
Arkadiusz Bereza

\section{Literatura}

Bereza A., Sąd Najwyższy 1917-2017. Prezesi, sędziowie i prokuratorzy Sądu Najwyższego, Warszawa 2017.

Bereza A., Sadownictwo pokojowe w guberni lubelskiej na tle Królestwa Polskiego (1876-1915), Lublin 2004.

Bereza A., Sadownictwo zamojskie - od czasów Ordynacji po wspótczesność, Zamość 2005.

Czubara K., Dawniej w Zamościu. O skarbach, duchach i czartach, stawnych generałach, poetach, wizytach dostojnych gości, wielkich balach, pojedynkach i kurtyzanach, Zamość 2005.

Gudowski J., Toga i biret - historia i wspótczesność urzędowego stroju sędziego, [w:] Ars et usus. Księga pamiatkowa ku czci Sędziego Stanisława Rudnickiego, Warszawa 2005.

Kędziora A., Encyklopedia Miasta Zamościa, Chełm 2000.

Klukowski Z., Zamojszczyzna 1918-1959, Warszawa 2017.

Lewandowski J., Sadownictwo w Królestwie Polskim w czasie I wojny światowej. Okupacja austro-węgierska, „Annales UMCS. Sectio F” 1974, t. 29.

Litwin J., Strój urzędowy (szarfa i toga) w sądownictwie polskim 1917-1965, „Czasopismo Prawno-Historyczne" 1966, nr 1.

Maleszyk R., Funkcjonowanie austriackich sądów wojskowych na Lubelszczyźnie w latach 19151918, „Annales UMCS. Sectio F” 2013, t. 68, nr 1-2.

Maleszyk R., Organizacja austriackich władz wojskowych na Zamojszczyźnie w latach 1915-1918, „Archiwariusz Zamojski” 2014.

Materniak-Pawłowska M., Ustrój sądownictwa powszechnego w II Rzeczypospolitej, Poznań 2003. Mazurkiewicz J., Policha L., Dzieje sądownictwa lubelskiego w latach 1915-1944 (maszynopis). Radziejewski K., Pożegnanie pułkownika Fiszera z Zamościem, „Archiwariusz Zamojski” 2007. Sawa B., Byta sobie Hyża, „Tygodnik Zamojski” 1993, nr 12.

Suleja W., Tymczasowa Rada Stanu, Warszawa 1998.

Szwarc W., Działania Tymczasowej Rady Stanu i Rady Regencyjnej na rzecz przejęcia cywilnego zarządu w Królestwie Polskim (1917-1918), [w:] Studia z historii państwa, prawa i idei, red.

A. Korobowicz, H. Olszewski, Lublin 1997.

Winnicki Z., Rada Regencyjna Królestwa Polskiego i jej organy (1917-1918), Wrocław 1991. Wróbel P., Listopadowe dni - 1918. Kalendarium narodzin II Rzeczypospolitej, Warszawa 2018.

W.S. [Wacław Salkowski], Historja Polskich Sądów Obywatelskich w Lublinie, „Biuletyn Towarzystwa Prawniczego w Lublinie" 1916, nr 1.

\section{SUMMARY}

During World War I, after the evacuation of the Russian authorities, a local grassroots judiciary system was established in July 1915 in Zamość and surroundings on the initiative of local lawyers. It operated for a short period and then was disbanded by the Austrian occupation authorities. However, the courts of the lowest instance remained, bound within the instance system with the occupation administration and military courts. In Zamość, the Magistrate's Court and the Military Regional (District) Court were functioning. Following the proclamation of the Act of 5 November of 1916 by the German and Austro-Hungarian Emperors, according to the provisions contained therein, the work aimed at handing over the judiciary in the occupied territories of the Kingdom of Poland to Polish hands was commenced. On 1 September 1917, the courts of the Kingdom of Poland were opened, including the Magistrate's Court in Zamość. As a result of the initiative of the municipal authorities of Zamość and local social organizations, the Regency Council of the Kingdom of Poland decided to establish the District Court of the Kingdom of Poland in Zamość. It was inaugurated on 1 June 1918 with Romuald Jaśkiewicz as its President, who had previously been the justice of peace of Zamość. The court was composed of four district judges, four investigating judges and one 
district prosecutor and three deputy prosecutors. These positions were assumed by attorneys in law, lawyers coming from Galicia, as well as Polish lawyers who had returned from Russia torn by the civil war. Lower positions such as investigative judges were also assumed by trainee judges. In the years 1918-1919, significant rotation of personnel in these positions could be observed. The Zamość District covered four counties (in Polish: powiaty): Zamość, Biłgoraj, Hrubieszów and Tomaszów, with 19 peace courts operating in their respective areas. They comprised two magistrates' courts in Zamość, covering the so-called municipal district and rural district. These were presided by Zygmunt Kostkiewicz and Adam Sajkiewicz. In November 1918, the courts of Zamość began to issue judgements "on behalf of the Republic of Poland", and soon afterwards these courts were seated in the Zamoyski Palace refurbished for that purpose.

Keywords: judiciary; courts of the Kingdom of Poland; magistrates' courts; Zamość; judges; prosecutors; investigative judges; Zamoyski Palace

\section{STRESZCZENIE}

W czasie I wojny światowej, w lipcu 1915 r. po ewakuacji władz rosyjskich, w Zamościu i jego okolicach z inicjatywy miejscowych prawników powstało sądownictwo obywatelskie. Funkcjonowało krótko, zostało rozwiązane przez austriackie władze okupacyjne. Utrzymano jednak sądy najniższej instancji, wiążąc je instancyjnie $z$ organami administracji okupacyjnej i sądami wojskowymi. W Zamościu funkcjonował sąd pokoju i wojskowy sąd obwodowy (powiatowy). Po wydaniu przez władców Niemiec i Austro-Węgier aktu 5 listopada z 1916 r. zgodnie z zawartą w nim zapowiedzią przystąpiono do prac mających na celu przekazanie w polskie ręce wymiaru sprawiedliwości na okupowanych terenach Królestwa Polskiego. W dniu 1 września 1917 r. otwarto sądy królewsko-polskie, a wśród nich sąd pokoju w Zamościu. W wyniku inicjatywy władz miejskich Zamościa i lokalnych organizacji społecznych Rada Regencyjna Królestwa Polskiego podjęła decyzję o utworzeniu królewsko-polskiego Sądu Okręgowego w Zamościu. Został on uroczyście otwarty w dniu 1 czerwca 1918 r., a jego prezesem mianowano dotychczasowego zamojskiego sędziego pokoju Romualda Jaśkiewicza. W skład sądu weszło czterech sędziów okręgowych, czterech sędziów śledczych, a także prokurator okręgowy i trzech podprokuratorów. Stanowiska te objęli adwokaci, prawnicy pochodzący z Galicji oraz polscy prawnicy powracający z ogarniętej wojną domową Rosji. Niższe stanowiska (np. sędziów śledczych) obsadzane były również przez pierwszych aplikantów sądowych. W latach 1918-1919 można zaobserwować spory ruch kadrowy na tych stanowiskach. Okręg zamojski obejmował cztery powiaty: zamojski, biłgorajski, hrubieszowski i tomaszowski, z działającymi na ich obszarze 19 sądami pokoju. Wśród nich były dwa sądy pokoju w Zamościu, obejmujące tzw. okręg miejski i okręg wiejski. Na ich czele stali Zygmunt Kostkiewicz i Adam Sajkiewicz. W listopadzie 1918 r. sądy zamojskie zaczęły wydawać wyroki „w imieniu Republiki Polskiej”, a niedługo potem ich siedzibą stał się wyremontowany dla tych celów pałac Zamoyskich.

Słowa kluczowe: sądownictwo; sądy królewsko-polskie; sądy pokoju; Zamość; sędziowie; prokuratorzy; sędziowie śledczy; pałac Zamoyskich 